\title{
LEVEL OF INTEGRATION AMONG AGRITOURISM ACCOMMODATION SECTOR AND TRAVEL AGENCIES
}

\author{
Aleksandra Vujko, Tamara Gajić², Miloš Dragosavac ${ }^{3}$, Branka Maksimovič $^{4}$, \\ Milutin Mrkša $a^{5}$
}

\begin{abstract}
Summary
Many researchers consider agritourism as a major agent of local development, but there is still a lack of awareness about the importance of networking and integration among agritourism accommodation sector and travel agencies, and the economic benefits in terms of livelihood enhancement.This paper analyses selected agritourism accommodation facilities and travel agencies in which we indicate positive experiences: first, in term of guest satisfaction (guests of 23 accommodation facilities) and second, among employees in travel agencies. This paper actually analyses the level of integration implemented in agritourism, and makes the point that cooperation between travel agencies and agritourism facilities needed to be at a much higher level.
\end{abstract}

Key words: agritourism, travel agencies, integration

JEL: Q15, R11

\section{Introduction}

Tourism is a factor of numerous changes in rural areas. Primarily due to the whole range of services, activities and complementary content such as agrotourism, recreation,

1 Aleksandra Vujko Ph.D., Lecturer, Novi Sad Business School, Vladimira Parića Valtera Street no. 4, Novi Sad, Serbia, Phone: +381 64914 26 45, E-mail: aleksandravujko@yahoo.com

2 Tamara Gajić Ph.D., Professor of professional studies, Novi Sad Business School, Vladimira Perića Valtera Street no. 4, Novi Sad, Serbia, Phone: +381 63565 544, E-mail: gajic tamara@, yahoo.com

3 Miloš Dragosavac, Assistent, Novi Sad Business School, Vladimira Parića Valtera Street no. 4, Novi Sad, Serbia, E-mail: dragosavac.vps@gmail.com

4 Branka Maksimović, Ph.D. Professor of professional studies, Novi Sad Business School, Vladimira Parića Valtera Street no. 4, Novi Sad, Serbia

5 Milutin Mrkša, Ph.D., Lecturer, Novi Sad Business School, Vladimira Parića Valtera Street no. 4, Novi Sad, Serbia

EP 2017 (64) 2 (659-670) 
education, cultural events etc. (Randelli et al., 2014). Vujko and Gajić (2014) observes rural tourism as a key factor of rural areas revitalisation process with a special emphasis on problems and current condition of rural tourism in Serbia, assuming that such position is important in the new identity of Serbian village. According to Petrović (2014), it is estimated that about 300 rural households with 8,000 beds offer services and realize over 150,000 overnights annually (Vujko et al., 2016). Agritourism is significant factor of sustainable rural development (Petrović et al., 2017). The total offer comprises about 8,000 beds. Average length of stay in a household is 2.8 days (Petrović, 2014). It is evident that the number of households constantly increases. Due to this, many family farms have to look for new ways to survive and one solution is to host tourists in the family property. According to Iorio and Corsale (2010), this kind of enterprises can bring several economic benefits, including increased farm gross income (when the family owns the farm), the generation of cash flow and the creation of employment opportunities for family members.

Travel Agencies have been recognised as a vital component of agritourism and have become an integral part of travel and tourism industry at global (Topolšek et al., 2014). These trends must be considered unique (Vujko, Gajić, 2014a), as there are tourists all over the world with the same or similar motives. According to Aguiar-Quintana et al., (2016), travel agencies acting as intermediaries between corporate clients and suppliers. Recent studies have shown that the travel agencies are becoming increasingly aware that multidimensionality require collaboration among various providers involved in the chain as well as agritourism accommodation sector, all necessary for the survival and development of sustainable destinations (Sigala, 2008; Oroian and Gheres, 2012; Topolšek et al., 2014).

The study started from the hypothesis $\mathrm{H}$ that there is a need for integration among travel agencies and accommodation capacity. The aim of the paper is to highlight the importance of the integration of travel agencies and accommodation capacity and to reveal the reason of insufficient integration. Questionnaire survey was conducted in 7 (seven) municipalities in Serbia on 164 respondents. The authors used descriptive statistics and multivariant analysis and data processing in IBM SPSS Statistics 19 programme which lead to certain conclusions. The obtained results will have wide application in numerous aspects of multifunctional agriculture and other economy segments in rural areas. The results of questionnaire survey will contribute to identify particular problems that have to be overcome and to follow directions to integrate agritourism accommodation sector and travel agencies in Serbia.

\section{Literature review}

Nickerson et al. (2001) say that rural area is the basic resource for the development of agritourism and that this tourist activity relies on the city residents' need for peace and outdoor space for recreation. Such activities involve staying in rural and natural environment, educational visits, recreational activities or selling agricultural and homemade products (Sznajder et al., 2009; Petrović et al., 2017). According to 
Petrović et al., (2017), agritourism is part of so-called alternative types of tourism, which appeared in 1980s as a consequence of the 'green consumption' trend, as well as a consequence of the awareness of travelling in accordance with the environmental protection. In their papers on agritourism, Nilsson (2002) and Petrović et al., (2017) define agritourism as an essential segment of rural tourism. According to Nilsson, rural tourism is generally based on rural environment, while agritourism is based exclusively on farms and farmers' offer.

The development of agritourist activities in Serbia does not have a long tradition because a more organized flow of visitors in these areas began to take place about the middle of the 70 s of the $20^{\text {th }}$ century (Petrovic et al., 2017). In Serbia, agritourism is recognized as an important factor of multifunctional rural development. According to Petrović et al (2017), this form of tourism should be one of the main potential and a factor of integral development of rural areas in Serbia.

According to research conducted by Aguiar-Quintana et al., (2016), the most of the studies relating to travel agencies tries to identify three main strategies for business improvement: (1) strategies related to service quality of the supplier (2) strategies focused on the demand side and (3) strategies related to the efficiency of the supplier. It can be said that some research studies have been conducted from the perspective of tourists (Aguiar-Quintana et al., 2016; Del-Chiappa, 2013; Kuo et al., 2013). These studies aim to increase aspects such as motivations and attitudes, the need to travel with the agency and behavior toward travel agencies. Enrique-Bigné et al., (2005) states that there is a positive relationship between perceived service quality and business performance and that the new communications technologies, such as the Internet has an enormous impact on the intermediation function of agencies.

According to Medina-Muñoz and García-Falcón, (2000), all tourism organizations have relationships with other entities (i.e. suppliers, distributors, competitors, public organizations, governments, etc), and the new technologies, particularly the Internet, are forcing them to change their traditional modes of operation. Same authors state that potential benefits of such integrations include more sales from travel agencies, appropriate commission levels, additional and improved promotional and advertising support by travel agencies, and compatibility of travel agent clientele with accomodations facilities’ properties (Medina-Muñoz, García-Falcón, 2000).

\section{Research Methodology}

This study was conducted in the city of Novi Sad eminent travel agencies and Fruška Gora Mountain accommodation facilities, located in Vojvodina, Serbia. We examined the 164 guests of 23 accommodation facilities from seven places on Fruška Gora Mountain: Petrovaradin, Sremski Karlovci, Čortanovci, Ledinci, Sremska Kamenica, Erdevik and Banstol, and 37 employees in 16 travel agencies located in the city of Novi Sad. The survey was conducted between April and August 2015. The paper was divided into two parts. In the first part of the paper were examined the guests of accommodation facilities (Table 1). 
Participants were asked about the main reason for visiting selected objects, and the influence of travel agencies in the selection of the accommodation facilities. There was $(57.3 \%)$ of females and males (42.7\%). Most respondents were in the age categories $21-30(50.0 \%)$ and $31-40(30.5 \%)$ and married (34.4\%) and held a high school degree (53.4\%).

The survey questionnaire contains a number of 36 questions relate to the ranking of different positions according to the criteria of tourists satisfaction with Fruška Gora Mountain accommodation capacity. In order to measure the attitudes of tourists, a five-point Likert scale of importance has been used. The paper presents the data factor analysis of satisfaction of seven subscales. The factor analysis, with using the method of extraction - Analysis of the main components (PCA), has determined one-dimensional and factorial validity of each of the factors. The key is formed on the basis of the model used in the study of Albacete et al., (2007).

Some of the most important questions that needed to be answered were: whether there is a need for integration and what are the factors influencing integration among travel agencies and agritourism accommodation facilities. And to answer it, three low-level hypotheses were formed: h1 - Tourists gladly and often visited accommodation facilities on the Fruška Gora Mountain; h2 - Tourists find out all the information by themselves, not via travel agency; h3 - Tourists believe that the travel agencies in their offer should have accommodation facilities from the Mountain.

The second part of the paper attempts to determine the involvement level of rural destinations in the tourist offer of travel agencies. Employees were asked whether they have mentioned facilities in their itineraries, and they were asked to provide a detailed explanation of their "point of view". Within this group of variables the lower-level hypothesis has been set: h4 Travel agencies in their offer do not have mentioned accommodation facilities; h5 - Travel agencies recognize the importance of integration with accommodation facilities.

Table 1. Accommodation facilities by the place of establishment

\begin{tabular}{|l|l|}
\hline \multirow{5}{*}{ Petrovaradin } & Markiza Apartment \\
\cline { 2 - 3 } & Apartment Villa Studenjak \\
\cline { 2 - 2 } & Fortress Apartments \\
\hline \multirow{5}{*}{ Sremski Karlovci } & Rest House Karlovci \\
\hline & Rest House Belilo 69 \\
\hline & Rest House Karlovački konak \\
\hline & Rest House Putina \\
\cline { 2 - 2 } & Rest House Somin Lagum \\
\hline & Bungalows on Stražilovo \\
\hline & Eco Camping Fruška gora \\
\hline & Ecological Centre of Radulovački \\
\hline & Mountain Home Stražilovo \\
\cline { 2 - 2 } & Apartment Žeravica \\
\hline & Rooms Gajić \\
\cline { 2 - 2 } & Rooms Drahomira B\&B \\
\hline
\end{tabular}




\begin{tabular}{|l|l|}
\hline \multirow{2}{*}{ Cortanovci } & Stanković Villa \\
\cline { 2 - 2 } & Mountain Home Kozarica \\
\hline Ledinci & Apartment Dobro Prase \\
\hline \multirow{2}{*}{ Sremska Kamenica } & Villa Evangelina \\
\cline { 2 - 2 } & Guest house Kordun \\
\hline Erdevik & Rooms Keti \\
\hline \multirow{2}{*}{ Banstol } & Villa Banstol \\
\cline { 2 - 2 } & Rest House Banstolka \\
\hline
\end{tabular}

Source: Own calculations.

\section{Results and discussion}

Validity of subscales "Relations with tourists" was confirmed by factor analysis, main components method (Table 2). According to the Guttman - Kaiser Criterion, the first two factors are important, but first factor involves 2.2 times more variance than the other. Based on this we can conclude that the subscales is one-dimensional and homogeneous. The first factor comprises $44 \%$ of the variance, whereas the second factor comprises $21 \%$ of the variance.

Table 2. The value of the characteristic roots and percentage of coverage of the variance of the first and the second factor

\begin{tabular}{|l|l|l|l|}
\hline & Component & $\begin{array}{l}\text { Characteristic values } \\
\Lambda / \text { Eigenvalue }\end{array}$ & \% Coverage of Variance \\
\hline \multirow{2}{*}{ Satisfaction } & 1. & 2.637 & 43.945 \\
\cline { 2 - 4 } & 2. & 1.286 & 21.441 \\
\hline
\end{tabular}

Source: Own calculations

According to factor loading analysis, presented in Table 3, we may conclude that all items, have significant values of factor loading which pointed out mutual measurement subject.

Table 3. Saturation factor for the item "Relations with tourists" as the main feature of the tourism offer - Factor Analysis

\begin{tabular}{|l|l|}
\hline \multicolumn{1}{|c|}{ Responses } & Extraction \\
\hline Household members know the traditions, customs and history of their village & .748 \\
\hline $\begin{array}{l}\text { Household members are engaged in activities that make our visit more } \\
\text { complete (souvenirs made, weaving workshops etc.) }\end{array}$ & .509 \\
\hline $\begin{array}{l}\text { Household members give us good advice and suggestions regarding activities } \\
\text { that make our visit complete }\end{array}$ & .690 \\
\hline $\begin{array}{l}\text { Household members give us the interesting information about rural food } \\
\text { from the villages }\end{array}$ & .612 \\
\hline Household members treat us with kindness and warmth & .687 \\
\hline
\end{tabular}




\begin{tabular}{|l|l|}
\hline \multicolumn{1}{|c|}{ Responses } & Extraction \\
\hline Household members are friendly toward us & .705 \\
\hline Household members know the traditions, customs and history of their village & .748 \\
\hline
\end{tabular}

Source: Own calculations

There are 970 registered (Petrović, 2014) AAFs (agritourism accommodation facilities) in rural areas of Serbia. The total offer in agritourism is approximately 8,000 beds. Average stay of tourists in an AAFs is 2.8 days (Petrović, 2014). According to Pena et al., (2013), agritourism accommodation facilities are frequently included into the valorisation system with the aim of offering an objective estimation of the quality standard for the tourists (Pena et al., 2013). The results seen in Table 2 and Table 3 show that tourists are very satisfied with the accommodation facilities from Fruška Gora Mountain, so, the analysis of the data confirmed lower-level hypothesis h1 that the tourists gladly and often visited accommodation facilities on the Fruška Gora Mountain.

Table 4. Did you come here via a travel agency?

\begin{tabular}{|l|l|l|l|}
\hline \multicolumn{2}{|c|}{ Responses } & Frequency & Percent \\
\hline Valid & No & 164 & 100 \\
\hline
\end{tabular}

Source: Own calculations

Graph 1. Did you come here via a travel agency?

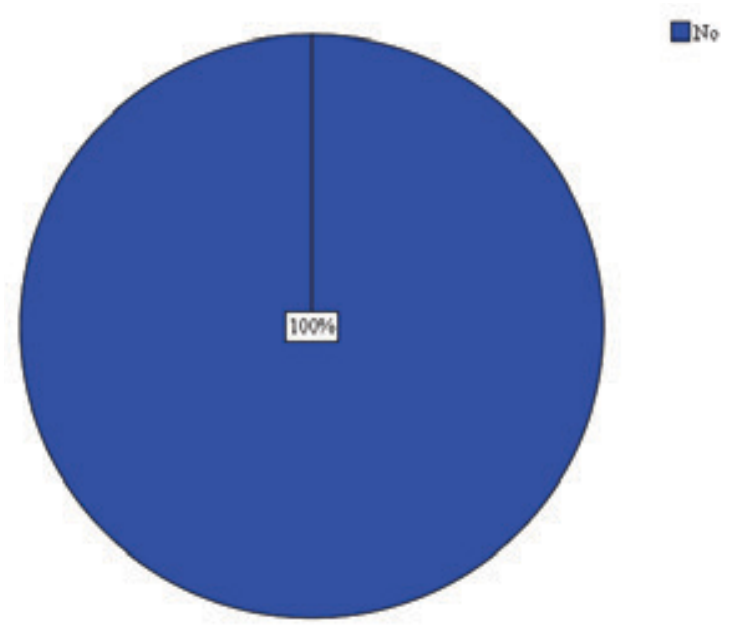

Source: Own calculations

According Brandon-Jones et al., (2016), a professional service (travel agencies), primarily acting as information supplier and the role of tourist could be seen as 
relatively passive. Silva and Gonçalves (2016) suggest that the secret of competitive advantage is the combination of on-line and off-line marketing. The travel agencies role as intermediary requires a high degree of communication and cooperation between customers and suppliers (Aguiar-Quintana et al., 2016). For this reason the tourist offer in the agency should be concentrate on what tourists want to buy". The analysis of the data from Table 4 and Graph 1 shows that no one of the tourists did not come through the agency, which was confirmation of lower-level hypothesis h2 that tourists find out all the information by themselves, not via travel agency.

Diverse offer represents the true capabilities of the travel agency in the mind of the user. Travelling is easier, booking is easier and tourists will return to that travel agency. Furthermore, these cooperation conditions could represent major sources of competitive advantage for both travel agency and accommodation facilities. Some of supporting factors for this finding are displayed in Table 5 and Graph 2 which was confirmation of lower-level hypothesis $h 3$ that tourists believe that the travel agencies in their offer should have accommodation facilities from the Mountain.

Table 5. Do you think that the travel agencies should have a specialized offer of accommodation facilities?

\begin{tabular}{|l|l|l|l|}
\hline \multicolumn{2}{|c|}{ Responses } & Frequency & Percent \\
\hline Valid & Yes & 164 & 100 \\
\hline
\end{tabular}

Source: Own calculations

Graph 2. Do you think that the travel agencies should have a specialized offer of accommodation facilities?

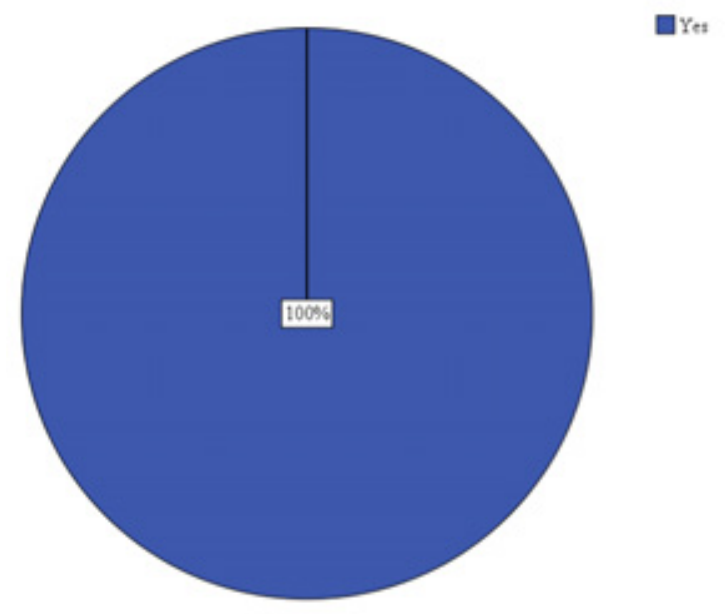

Source: Own calculations 
According to Medina-Muñoz and García-Falcón, (2000) the role of travel agencies is expected to grow in importance for several reasons: they are very close to the industry's consumers, they are key players in the spreading of new technologies, including reservation; there are promoters of the destination etc. It is important that agencies understand importance of linking and its role in the development of destination.

Table 6. Do you have mentioned accommodation facilities in your itineraries?

\begin{tabular}{|l|l|l|l|}
\hline \multicolumn{2}{|c|}{ Responses } & Frequency & Percent \\
\hline Valid & No & 37 & 100 \\
\hline
\end{tabular}

Source: Own calculations

Graph 3. Do you have mentioned accommodation facilities in your itinerary?

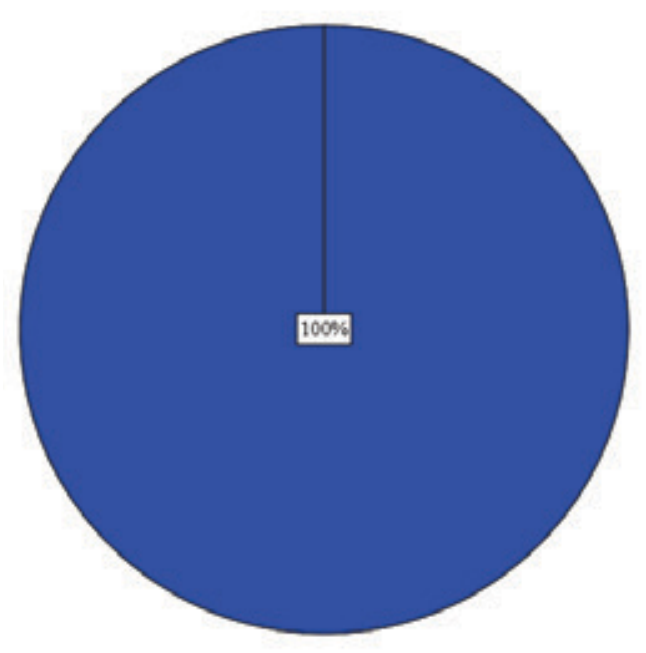

Source: Own calculations

According to data from Table 6 and Graph 3, we can conclude that the agency do not have mentioned accommodation facilities in their itineraries, which was confirmation of lover-level hypothesis h4.

Table 7. Tell us detailed explanation of your attitude?

\begin{tabular}{|l|c|c|}
\hline \multicolumn{1}{|c|}{ Responses } & Frequency & Percent \\
\hline There are not enough interested tourists & 6 & 16,2 \\
\hline We have not thought about it & 3 & 8,1 \\
\hline The owner does not see the interest in domestic tourism & 4 & 10,8 \\
\hline $\begin{array}{l}\text { Domestic tourism is the future, we are thinking in that } \\
\text { direction }\end{array}$ & 8 & 21,6 \\
\hline We plan as soon as possible to connect with some of them & 7 & 18,9 \\
\hline $\begin{array}{l}\text { Demand is growing, so we plan to turn our business towards } \\
\text { this form of tourism }\end{array}$ & 4 & 10,8 \\
\hline
\end{tabular}




\begin{tabular}{|l|c|c|}
\hline Sounds interesting, I'll think about it & 3 & 8,1 \\
\hline $\begin{array}{l}\text { We have not cooperated with the aforementioned facilities, but } \\
\text { in the future we want }\end{array}$ & 2 & 5,4 \\
\hline Total & 37 & 100,0 \\
\hline
\end{tabular}

Source: Own calculations

Graph 4. Detailed explanation of participants attitude?

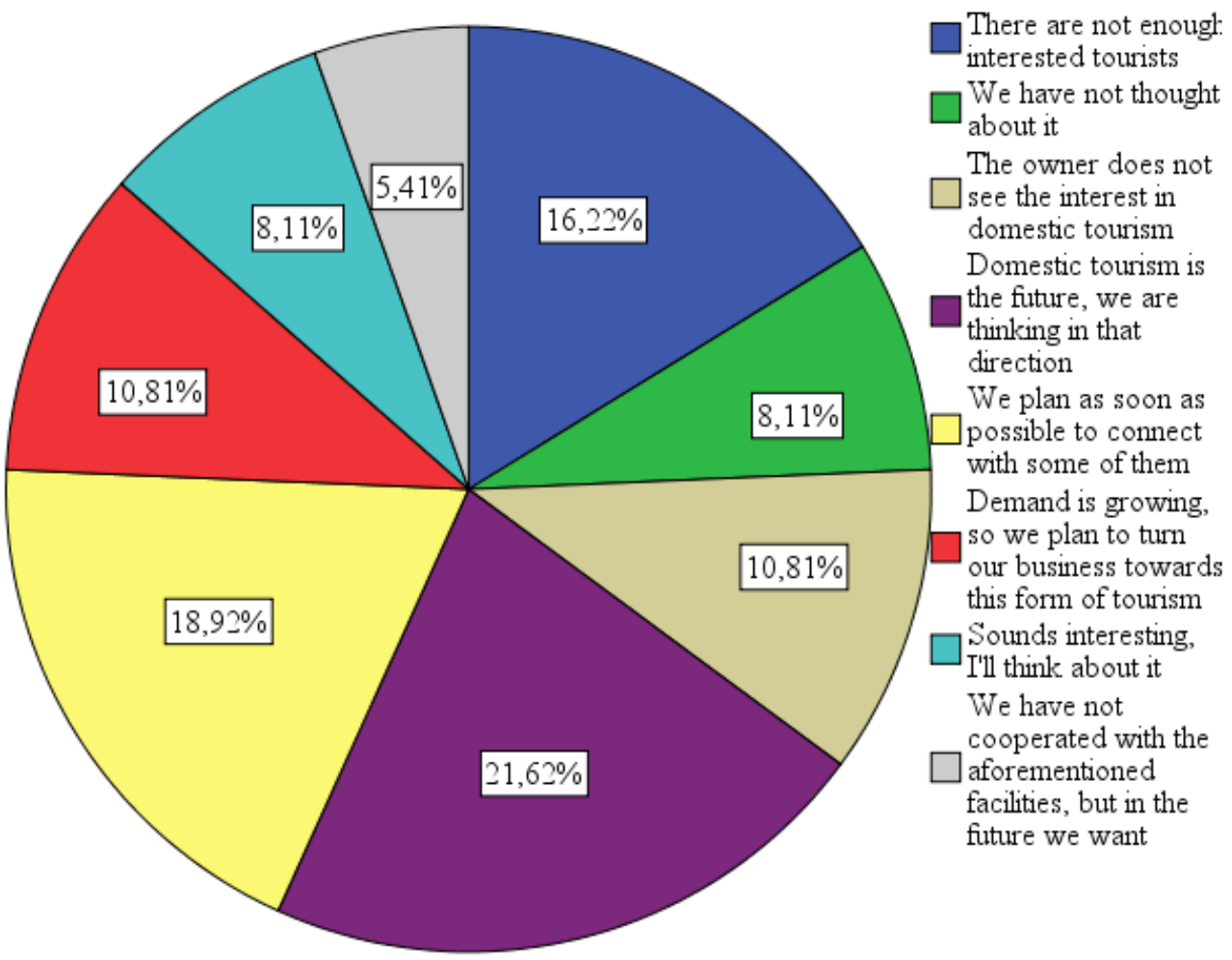

Source: Own calculations

In Table 7 and Graph 4, there is frequency of question: 'detailed explanation about why they do not have Mountain in their offer'. As it can be seen in Table 7, only three travel agency says that they are not thought about why they did'nt mentioned accommodation facilities in their itinerary. All the others, pointed to the importance of integration. In addition, "Look in the future" seems to be especially important in relationships between hotels and travel agencies. It means that travel agencies recognize the importance of integration with accommodation facilities, which was confirmation of lover-level hypothesis h5. 


\section{Conclusion}

This study integrates the similar opinions of tourists and travel agency managers through a qualitative study, and trying to understand the level of integration among agritourism accommodation sector and travel agencies and the possible actions they can take to increase the level of integration in the future. According to Petrović et al., (2017), agritourism ensure profit for the owners of the accommodation units, as well as the households, which they buy agricultural products from (cheese, kajmak (milk cream), vegetables, prosciutto, honey, brandy, wine etc.). It is estimated that there are about 300 rural settlements in which there are tourist activities in Serbia (Petrović, 2014). The destinations in agritourism are distributed in 67 municipalities and it can be said that is obvious significant increase of tourist visits to villages, especially in the villages of Vojvodina Province in northern part of Serbia. Rural development in Serbia has been defined as economic, social and ecological priority by the Government of the Republic of Serbia. Diversification of rural economy towards socially, economically and ecologically sustainable form aims at improving the quality of living, lowering the poverty, as well as against social and ecological degradation (Vujko and Gajić, 2014a; Vujko et al., 2016).

The main conclusions of this study suggest that in order to have successful corelations between travel agency and accommodation facilities each entity should communicate in a timely, precise, satisfying, respecting, and credible manner. Also, they must show more commitment or enthusiasm to maintain this relationship; show a strong sense of dedication; visionary ability and sense of innovations. They must seek advice one of the other.This conclusion is explained in the light of the concepts which considers the tourists as the focus of decisionmaking.

\section{References}

1. Albacete-Saez, C., Fuentes-Fuentes, M., Llorens-Montes, F (2007): Service Quality Measurement in Rural Accommodation, Annals of Tuorism Research, Vol. 34, pp. 45-65.

2. Aguiar-Quintana, T., Moreno-Gil, S., Picazo-Peral, P. (2016): Howcould traditional travel agencies improve their competitiveness and survive? A qualitative study in Spain, Tourism Management Perspectives, Vol. 20, pp. 98-108

3. Brandon-Jones, A., Lewis, M., Verma, R., Walsman, C.M. (2016): Examining the characteristics and managerial challenges of professional services: An empirical study of management consultancy in the travel, tourism, and hospitality sector. Journal of Operations Management, Vol. 42-43, pp. 9-24.

4. Del Chiappa, G. (2013): Internet versus travel agencies: The perception of different groups of Italian online buyers. Journal of Vacation Marketing, Vol. 19, No. 1, pp. 55-66.

5. Enrique-Bigné, J., Andreu, L., Küster, I., Blesa, A. (2005): Quality market orientation: tourist agencies' perceived effects. Annals of Tourism Research, Volume 32, No. 4, pp. 1022-1038 
6. Iorio, M., Corsale, A. (2010): Rural tourism and livelihood strategies in Romania, Journal of Rural Studies, Vol. 26, pp.152-162

7. Kuo, N. T., Chang, K. C., Cheng, Y. S., Lai, C. H. (2013): Howservice quality affects customer loyalty in the travel agency: The effects of customer satisfaction, service recovery, and perceived value. Asia Pacific Journal of Tourism Research, Vol. 18, No. 7, pp. 803-822.

8. Medina-Muñoz, D., García-Falcón, J.M. (2000): Successful relationships between hotels and agencies. Annals of Tourism Research, Volume 27, No. 3 , pp. 737-762

9. Nickerson, N. P., Black, R. J., McCool, S.F. (2001): Agritourism: motivations behind farm-ranch business diversification. Journal of Travel Research Vol. 40, No. 1, pp.19-26

10. Nilsson, P. A. (2002): Staying on farms - an ideological background. Annals of Tourism Research, Vol. 29, No. 1, pp.7-24

11. Oroian, M., Gheres, M. (2012): Developing a risk management model in travel agencies activity: An empirical Analysis, Tourism Management, Vol. 33, pp. 1598-1603.

12. Petrović, M., Blešić, I., Vujko, A., Gajić, T. (2017): The role of agritourism impact on local community in a transitional society: a report from Serbia, Transylvanian Review of Administrative Sciences, Vol. 50, pp. 146-163

13. Petrović, M. D. (2014): Kvalitet agroturizma Vojvodine i njegov uticaj na stavove lokalnog stanovništva (Ph.D. thesis - in Serbian). University of Novi Sad, Faculty of Sciences, Department of Geography, Tourism and Hotel Management, Novi Sad, Serbia.

14. Pena A.I.P., Jamilena-Frias D.M., Molina M.A.R. (2013): Antecedents of loyalty toward rural hospitality enterprises: The moderating effect of the customer's previous experience, International Journal of Hospitality Management, Vol. 34, pp.127-137

15. Sigala, M. (2008): A supply chain management approach for investigating the role of tour operators on sustainable tourism: The case of TUI. Journal of Cleaner Production, Vol. 16, pp. 1589-1599.

16. Sznajder, M., Przezborska, L., Scrimgeour, F. 2009: Agritourism, Wallingford.

17. Silva, M.G., Gonçalves, M.H. (2016): Causal recipes for customer loyalty to travel agencies: Differences between online and offline customers. Journal of Business Research, Vol. 69, No. 11, pp. 5512-5518

18. Randelli F., Romei P., Tortora M. (2014): An evolutionary approach to the study of rural tourism: The case of Tuscany. Land Use Policy 38, 276-281

19. Topolšek, D., Mrnjavac, E., Kovačić, N. (2014): Integration of travel agencies with transport providers, Tourism Management Perspectives, Vol. 9, pp. 14-23

20. Vujko A., Gajić T. (2014): Opportunities for tourism development and cooperation in the region by improving the quality of supply - The "Danube Cycle Route" Case Study. Economic research, Vol. 27, No. 1, pp.847-860 
21. Vujko, A., Gajić, T. (2014a): The gouverment policy impact on economic development of tourism, Ekonomika poljoprivrede, Vol. 61, No. 3, pp. 789-804.

22. Vujko, A., Petrović, M., Dragosavac, M., Gajić, T., (2016): Differences and similarities among rural tourism in Slovenia and Serbia - perceptions of local tourism workers, Ekonomika poljoprivrede, Vol. 63, No. 4, pp. 1459-1469.

\title{
STEPEN INTEGRACIJE IZMEĐU SEOSKIH SMEŠTAJNIH KAPACITETA I TURISTIČKIH AGENCIJA
}

\author{
Aleksandra Vujko ${ }^{6}$, Tamara Gajić7 7 Miloš Dragosavac ${ }^{8}$, Branka Maksimovićn $^{9}$, \\ Milutin Mrkša ${ }^{10}$
}

\begin{abstract}
Sažetak
Mnogi istraživači smatraju agroturizam kaojedan od vodećih faktora razvoja turističkih destinacija. Međutim, još uvek postoji nedovoljno svesti o značaju povezivanja između glavnih nosilaca turističke delatnosti: smeštajnih kapaciteta i turističkih agencija. $U$ radu se analizira odnos između izabranih seoskih smeštajnih kapaciteta $i$ turističkih agencija, u kojima su identifikovana pozitivna iskustva: (ispitani su gosti 23 seoska smeštajna kapaciteta $i$ zaposleni u turističkim agencijama). Rad zapravo analizira stepen integracije smeštajnih kapaciteta i turističkih agencija u ruralnim sredinama, a rezultati ukazuju da bi nivo saradnje među njima morao biti na mnogo višem nivou.
\end{abstract}

Ključne reči: agroturizam, turističke agencije, integracija

6 Dr Aleksandra Vujko, predavač, Visoka poslovna škola strukovnih studija, Ulica Vladimira Parića Valtera br. 4, Novi Sad, Srbija, Phone: +381 64914 26 45, E-mail: aleksandravujko@yahoo.com

7 Profesor strukovnih studija dr Tamara Gajić, Visoka poslovna škola strukovnih studija, Ulica Vladimira Parića Valtera br. 4, Novi Sad, Srbija, Phone: +381 63565 544, E-mail: gajic tamara@yahoo.com

8 Miloš Dragosavac, asistent, Visoka poslovna škola strukovnih studija, Ulica Vladimira Parića Valtera br. 4, Novi Sad, Srbija, E-mail: dragosavac.vps@gmail.com

9 Dr Branka Maksimović, professor strukovnih studija, Visoka poslovna škola strukovnih studija, Ulica Vladimira Parića Valtera br. 4, Novi Sad, Srbija,

10 Dr Milutin Mrkša, predavač, Visoka poslovna škola strukovnih studija, Ulica Vladimira Parića Valtera br. 4, Novi Sad, Srbija, E-mail: mmrksa@gmail.com 